\title{
Efficacy of percutaneous cryoablation of renal cell carcinoma in older patients with medical comorbidities: Outcome study in 70 patients
}

\author{
Erich K. Lang, MD; ${ }^{*}$ Kan Karl Zhang, MD;† Quan Nguyen, MD; Leann Myers, PhD; Mahamed Allaf, MD; \\ Ivan Colon, $M D^{\S}$
}

*Johns Hopkins Medical Center, Baltimore, MD; 'Department of Surgery, Division of Urology, Duke University Medical Center, Durham, NC; §SUNY Downstate Medical Center, Brooklyn, NY

Cite as: Can Urol Assoc J 2015;9(5-6):E256-61. http://dx.doi.org/10.5489/cuai.2597

Published online May 13, 2015.

\section{Abstract}

Introduction: The aim of this study was to establish the efficacy of cryoablation for incidentally discovered small renal cell carcinomas in older patients with medical comorbidities.

Methods: We carried out a retrospective chart analysis of outcomes of 70 patients treated by cryoablation. The inclusion criteria were age $>56$ years, medical comorbidities (Charlson class I-III), and suitability for cryoablation established by urologists and interventional radiologists. In total, 43 patients were male, 27 female, and the age range was 56 to 89 . The lesions measured 1.5 to $4 \mathrm{~cm} ; 29$ were high-grade Fuhrman and 41 were low grade. All lesions were treated by 2 10-minute freezing cycles separated by an 8-minute thawing period. One to seven cryoprobes were inserted according to a preoperative, 3D computed tomography (CT)-based plan. Results: Results were assessed on follow-up CTs (at 8-9 months). Of the 70 patients, 68 were treated by cryoablations and surgical salvage procedures; these patients were free of disease for 23 to 72 months (mean 39). One patient experienced recurrence and the other was lost to follow-up. One or two cryoablations rendered 66 patients tumour-free and additional surgery rendered another 2 patients tumour-free. The location and configuration of the lesion affected outcomes. Of the 27 posterior lesions, there was 1 failure; of the postero-lateral lesions, there were 4 failures; of the anterior lesions, there were 5 lesions; finally of the 32 central or deep seated lesions, there were 9 failures. Implants with one and two cryoprobes had a high recurrence rate. Three major complications were managed by minor interventions. The mean hospitalization was 1.3 days and the procedure times were variable.

Conclusion: Percutaneous cryoablation is recommended as a minimally invasive nephron-sparing treatment for amenable lesions in older patients with medical comorbidities.

\section{Introduction}

A reassessment of current treatments for renal cell carcinoma (RCC), consisting principally of segmental resection or radical nephrectomy, is affecting patient survival and quality of life. The new World Health Organization reclassification assigns an increasing number of suspect mass lesions to the benign group, thereby reducing the number of RCCs. ${ }^{1}$ Moreover, statistical analysis has shown intercurrent disease to be the prevalent cause of death in older patients with medical comorbidities rather than the RCC. ${ }^{2}$ These pertinent facts suggest an increased role for surveillance or minimally invasive treatment modalities in this patient group. ${ }^{3-6}$ Cryoablation is one option; it can achieve cancer-specific survival in $96 \%$ to $100 \%$ of patients. ${ }^{7-11}$ We have undertaken a retrospective analysis of results of cryoablation in 70 older patients with medical comorbidities.

\section{Methods}

In total, 70 patients treated by cryoablation for amenable RCC lesions between November 2005 and February 2011 were part of our retrospective study. The diagnosis of mass lesions with malignancy characteristics was established by contrast-enhanced multidetector computed tomography (CT) or magnetic resonance imaging. The institutional review board approval was waved and informed consent was obtained from all patients. Urologists and interventional radiologists assessed patients and offered surgical treatment modalities, cryoablation or surveillance with appropriate supervision for each patient. The inclusion criteria for cryoablation were RCCs $<4 \mathrm{~cm}$ in size, age $>56$, and particularly coexistent medical comorbidities. Patient age ranged from 56 to 89 (mean 73.2) and 43 patients were male and 27 female. One or more comorbidities were present in all 70 patients. In total, 53 patients were class II Charlson comor- 
bidity index, 5 patients were class III, and 12 were class I. Hypertension was present in 67 patients, diabetes in 21, congestive heart failure in 6 , cardio-pulmonary disease in 11 , obesity in 8 , renal calculi in 3 , pulmonary emboli in 1 , emphysema in 1, prior cerebro-vascular accident in 2 , and hepato-renal syndrome in 1 .

All RCCs were clinical stage T1a, N0M0; 29 RCCs were high grade (Fuhrman) and 41 were low grade. Twelve RCCs were $<2 \mathrm{~cm}$ in diameter, 35 were 2 to $3 \mathrm{~cm}$, and 23 were 3 to $4 \mathrm{~cm}$. Thirty-three RCCs were in the posterior and posterolateral locations and exophytic ( $>50 \%$ of circumference projecting outside the renal capsule), 5 in the anterior location, and 32 in the central and deep location (Table 1).

During the study period, 105 younger patients with suspicious renal masses were advised against thermal ablation by our urologists and interventional radiologists and offered laparoscopic or segmental resection. Of the other group of 68 patients, 42 were referred for laparoscopic and 26 for open cryoablation due to location and difficulty to access the lesions percutaneously.

\section{Technique of cryoablation}

In contrast to prior cryoablation studies, the positioning of cryoprobes was planned preoperatively based on axial, coronal, and volume-rendering images (General Electric highspeed, Milwaukee, WI; and Somatom 40 slice Siemens, Erlangen). ${ }^{5,7,12-17}$ The number of cryoprobes (2.4 and $3 \mathrm{~mm}$, 4-cm freeze length, various shaft length, Endocare, Perc 24 system, Heathronics, Austin, TX) was determined by size, geometry, and morphology of the tumour to adequately cover the lesion with the resulting iceball. The probes were placed under CT guidance (contrast enhanced and 3D volume reconstruction) 1 to $1.5 \mathrm{~cm}$ apart, in a pattern akin to a radiation therapy implant, resulting in a freezing zone covering the lesion plus a 5-mm margin. ., $^{-111,15}$ Since cell-death is certain only within $3 \mathrm{~mm}$ of the iceballs margin (where a temperature of $-20^{\circ} \mathrm{C}$ can be attained), a $5-\mathrm{mm}$ safety margin is necessary. 5,7-11,15-17 To attain this pattern, 1 probe was placed in 12, 2 probes in 16, 3 probes in 19, 4 probes in 15, 5 probes in 6 , and 7 probes in 2 patients. The 7-probe-implant deployed the probes in 2 concentric rings, 3 and 4 respectively.

To prevent damage to adjacent structures (colon, duodenum, spleen, liver, pancreas and peritoneal lining) during the freezing cycle, we interposed a bolus of air, $\mathrm{CO}_{2}$, or saline. ${ }^{11,12,18,19}$ Under CT guidance, a catheter was introduced

$\begin{aligned} & \text { Table 1. Relationship of tumour-free status attained after } \\
& \text { one cryoablation to Fuhrman } \\
& \text { orade and location of the mass }\end{aligned}$
\begin{tabular}{lccc}
\hline Location & No. & \multicolumn{2}{c}{ Fuhrman grade } \\
\hline & & High* & Low* \\
\hline Posterior & 27 & $10(1)$ & $17(0)$ \\
Postero-lateral & 6 & $3(3)$ & $3(0)$ \\
Anterior & 5 & $4(3)$ & $1(1)$ \\
Central and deep & 32 & $12(8)$ & $20(1)$ \\
Total no. & 70 & 29 & 41 \\
\hline
\end{tabular}

*(n) number of failed cryoablations.

into the posterior para- or perirenal space using a 4-Fr micropuncture set. We infused a 400 to $700 \mathrm{~mL}$ air, $\mathrm{CO}_{2}$ or saline until a 2-cm separation of critical structures and iceball were obtained (Fig. 1). Because of problems with conductivity, air was favoured over saline, though its rapid reabsorption may have required more frequent replenishing of the bolus.

Each mass was treated by two 10-minute freezing cycles, separated by an 8-minute thawing period. The double freeze-thaw cycle has been shown to increase liquefaction necrosis and hence improve efficacy. ${ }^{20,21}$ The interposed thawing causes cells to "burst" which is important to ensure cell death..$^{5-11,20,21}$ During the freezing cycle, limited CTs are obtained every 3 to 4 minutes to affirm coverage of the lesion by the iceball. 5,7,8,12,14,20 To identify possible "skip zones," a contrast-enhanced CT was obtained after the second freeze cycle. In 5 patients the positions of 13 cryoprobes had to be adjusted or cryoprobes added to cover the "skip zone" by the iceball.

We performed follow-up CTs to assess for residual or recurrent disease for the first 43 patients 2 to 3 months after the initial cryoablation. Enhancement in the rim of the treated lesion was considered evidence of residual disease. However based on recent reports and our own experience, we dismissed early enhancement as a reliable finding of residual tumour. Therefore, in the remaining 27 patients, we performed the first follow-up examination 8 to 9 months after the cryoablation to eliminate false positives of inflammatory neovascularity. ${ }^{22,23}$

\section{Results}

Of the 70 patients treated for RCC, 68 were treated by cryoablation and some surgical salvage procedures; they were free of disease 23 to 72 months (mean 39) after completion of treatment. One patient was lost to follow-up and one

Table 2a. Outcome of cryoablation and salvage procedures

\begin{tabular}{|c|c|c|c|c|c|}
\hline \multirow{2}{*}{ Sequence of intervention } & \multirow[t]{2}{*}{ Procedures } & \multicolumn{4}{|c|}{ Outcome } \\
\hline & & Free of disease & Recurrence & False positive & Lost to follow-up \\
\hline First group: At 3 months follow-up & 43 cryoablations & 28 & 15 & 3 & \\
\hline Second group: At 9 months follow-up & 27 cryoablations & 21 & 5 & & 1 \\
\hline Total no. & 70 & 49 & 30 & 3 & 1 \\
\hline
\end{tabular}




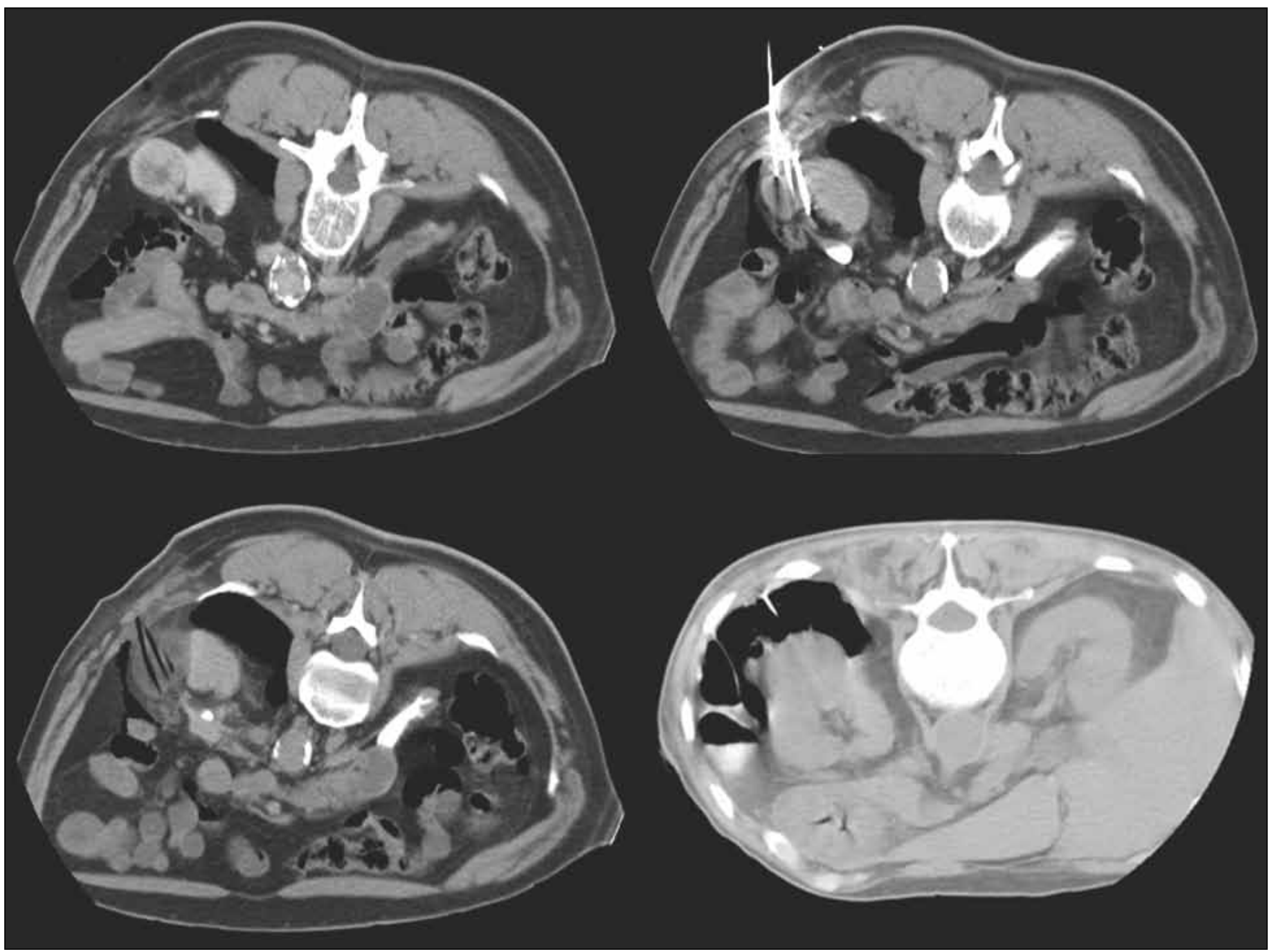

Fig. 1a. A computed tomography scan showing infusion of a 400 to $700 \mathrm{~mL}$ air, $\mathrm{CO} 2$ or saline until a 2-cm separation of critical structures and iceball were obtained.

patient is alive with recurrent metastatic disease currently on chemotherapeutic management with sunitinib, a tyrosine kinase inhibitor.

At the 3-month follow-up of the first 43 patients, 28 patients achieved tumour-free status as established by enhanced CTs (Table 2a). Of these 43, 3 patients were retreated by segmental resections for a recurrence suspected on the basis of the 3-month follow-up CTs; they were tumour-free on histopathology of the resected segment (Table 2a). In total of the first group of 43, 31 were tumourfree after the first cryoablation. Likely the observed recur- rence in 15 patients was due to inflammatory neovascularity that often perseveres up to 6 months after cryoablation. ${ }^{22,23}$ Perfusion CT may offer criteria to differentiate inflammatory from neoplastic neovascularity. ${ }^{24}$ After removing the 3 patients with false positives, we determined that after the second cryoablation the remaining 12 patients presumed to have residual or recurrent disease achieved tumour-free status (Table 2a) (Fig. 2).

In the second group of 27 patients, at the 9-month followup, 21 were tumour-free, 5 had recurrence and 1 patient was lost to follow-up (Table 2a). Of the 5 patients with

\begin{tabular}{lccc}
\hline \multicolumn{4}{l}{ Table 2b. Outcome of cryoablation and salvage procedures for the patients who recurred in the second group (n = 5) } \\
\hline Sequence of intervention & Procedures & Free of disease & Recurrence \\
\hline First salvage intervention $(n=5)$ & 3 cryoablations & 2 & $1(x)$ \\
& 2 segmental nephrectomies & 1 & $1(y)$ \\
Second salvage intervention $(n=2)$ & 1 segmental nephrectomy $(x)$ & & 1 \\
& 1 radical nephrectomy $(y)$ & 1 &
\end{tabular}


recurrence, 3 had repeat cryoablations and 2 had segmental resections (Table 2b). Repeat follow-up CTs showed 1 recurrence after cryoablations and 1 recurrence after segmental resections (Table $2 b$ ). A radical nephrectomy rendered one of these patients tumour-free (follow-up 38 months) and a segmental resection failed to control the tumour in the other patient (Table $2 \mathrm{~b}$ ). This patient is now being followed with lung and brain metastasis under chemotherapy.

In 65 patients the cryoprobes produced a satisfactory iceball covering the lesion. In 5 patients the position of 13 probes had to be adjusted to eliminate skip-zones.

Configuration, morphology, and geometry of the lesion greatly influenced the potential for a successful ablation. It was difficult to create an adequate iceball to cover small lesions with 1 or 2 cryoprobes. ${ }^{5-7,10,12,20,25-27}$ Hence the high failure rate of $38 \%$ in this group ( 8 of 21 patients). Conversely, when using 3 or more cryoprobes, the rate of failure dropped to $18 \%$ (9 of 49 patients) (Table 3).

Location of the lesion was a major factor governing success or failure of the ablation procedure $(p=0.0001)$ (Table 4). Size had no significant impact on attaining tumour-free status $(p=0.3753)$. In 27 exophytic posterior lesions, we recorded only 1 failure, and this was in a lesion that was implanted with only 1 cryoprobe (Table 4). In anterior-located lesions we had 4 failures in 5 patients. However, again 1 patient had 1 cryprobe in the high-Fuhrman grade lesion. (Table 4). In the 32 lesions in the central and deep locations, we had 9 failures $(28 \%)$. However, 4 failures occurred in patients in whom 1 or 2 cryoprobes had been used (Tables 4).

Grade (Fuhrman) of tumour significantly influenced outcome and tumour-free survival $(p=0.0001)$. Of the 29 highgrade tumours, 14 (48\%) were tumour-free; of the 41 lowgrade tumours 39 were tumour-free.

In 11 patients, saline $(n=6)$ and air $(n=5)$ interpositions were performed to safeguard adjacent structures against freeze damage. We observed no damage to 4 colons, 2 duodenums, 3 livers, 1 spleen, 1 pancreas, and 1 ureteropelvic junction at risk.

We encountered 3 major and 5 minor complications (Clavian classification). In 1 patient, active post-ablation bleeding was treated first with blood transfusions and then embolization. In a second patient, a substantial perirenal and pararenal hematoma developed hours post-cryoablation, causing hypotension and mandating 2 blood transfusions. In a third patient, a urine leak developed the day following cryoablation of a central lesion abutting urothelium, which had not been protected by warm saline perfusion. Drainage by a double "J" catheter for 6 weeks resulted in closure of the dehiscence. Two minor hematomas resolved without sequellae as did 2 febrile reactions.

Of the total 70 patients in this study, 52 were discharged after 5 to 8 hours of observation, 9 patients after overnight admission to the short stay unit, 7 patients were admitted for 2 days, 1 patients was admitted for 3 days, and 1 patient was hospitalized for a total of 2 weeks.

Operating times varied widely depending on size, complexity of the lesion, and number of cryoprobes deployed as well as use of ancillary interventions, such as bolus interposition and retrograde ureteral perfusion with warming solutions, from 42 to 225 minutes (mean 98 minutes).

\section{Discussion}

The management of malignant renal masses has been significantly influenced and altered by two factors. The first influential factor is that despite the increase in suspect renal masses identified on abdominal CTs, the numbers assigned to the RCC group has declined reflecting the new reclassification criteria of the World Health Organization. ${ }^{1}$

A revision of indications for surgery is the second factor. While prompt surgical excision of renal malignancies had been the accepted standard of care, recent data have shown conclusively that an increase in size from $1.5 \mathrm{~cm}$ to $3 \mathrm{~cm}$ does not alter the rate of tumour-free survival.,3,28-30 Moreover, recent reports have shown minimal metastatic progression during surveillance or follow-up after cryoablation, which allows delay of definitive surgery without affecting tumour-free survival. ${ }^{3,4,30}$ To further improve identification of recurrent tumour by imaging studies, the use of CT-guided biopsy has been advocated. ${ }^{31}$ Furthermore, recent statistical analysis has shown the cause of death in older patients with RCC and medical comorbidities to be more likely intercurrent disease than RCC. ${ }^{2}$ These newly emerged concepts make surveillance or management by minimally invasive techniques, such as cryoablation, a viable alternative to surgery, for older patients with medical comorbidities. ${ }^{3,4,30}$ While segmental or laparoscopic resection remains the gold standard for treating amenable RCCs, recent data show acceptable results-12,14,25-27,32 (98\% tumour-free survival for segmental resection and a $93 \%$ to $98.7 \%$ tumour-free survival for cryoablation. ${ }^{5-11,14,17,20,25-29,32-34}$

The efficacy of cryoablation treating RCCs in our patients is $97 \%$ (68 of 70) based on imaging follow-up criteria (lack of enhancement of ablated tissue), which is similar to that reported in the literature $(93.3 \%-98.7 \%))^{7-9,12,14,22,23,25-27,32,34-36}$

Similar to reported experiences, we found that lesion location greatly affected the rate of success of cryoablation. 5,25,26 For lesions in the anterior location, our rate of success was only $20 \%$, for central or deep seated lesions $68 \%$, and for posterior lesions $96 \%$. Steriotactic percutaneous cryoablation may offer advantages for lesions in such locations. ${ }^{13}$ Conversely location of lesions did not affect tumour-free status attained by open or laparoscopic segmental resection, though it adversely affected the rate of complications. ${ }^{28,29,33,35}$ This raises the question of whether an anterior or deep location of a lesion should be an exclusion 


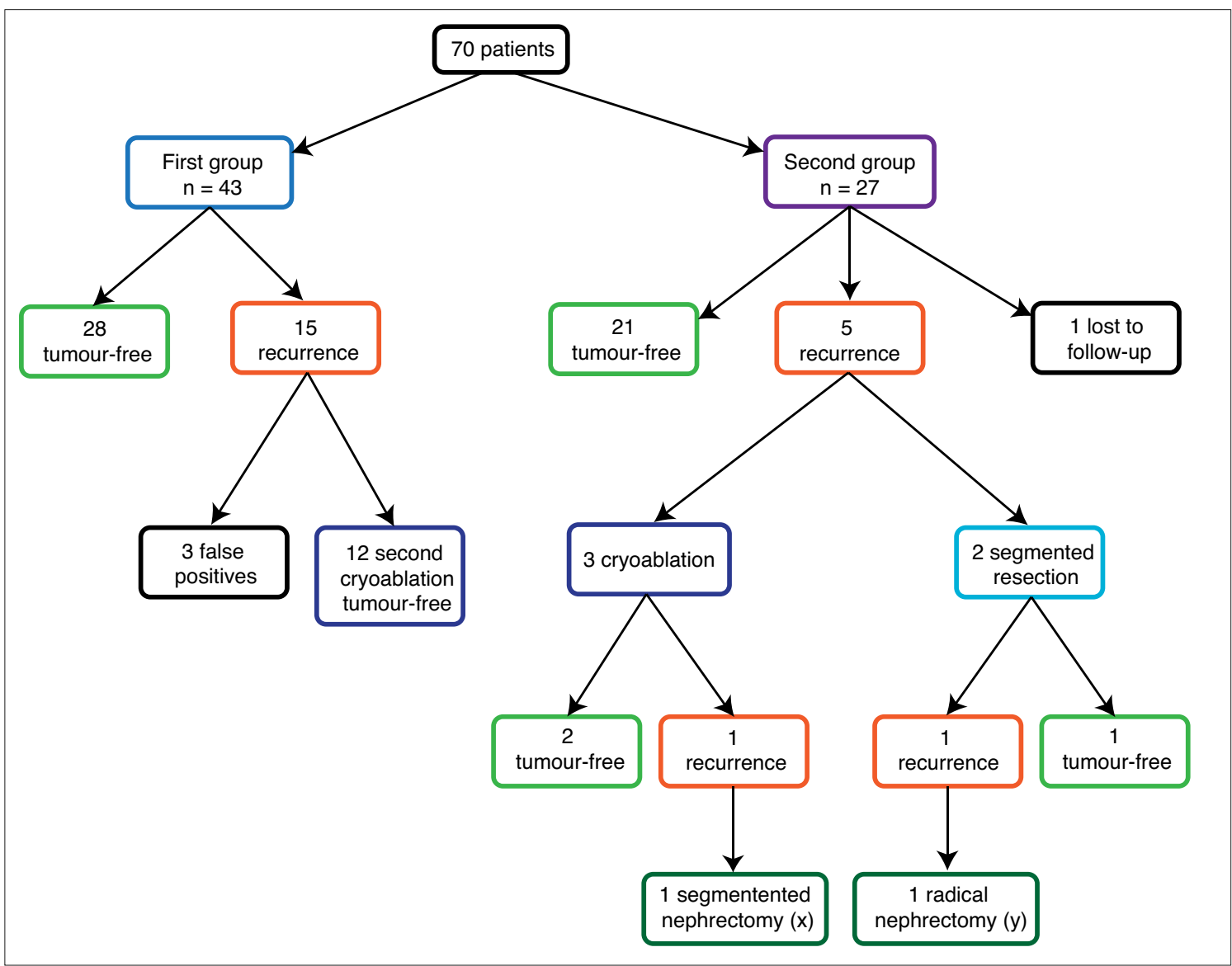

Fig. 2. Patient outcomes.

criterion for cryoablation, and whether surgical management should be recommended in these cases. ${ }^{16,25-29,32,33,36}$

\section{Conclusion}

We have found that hydro-displacement of critical organs and protection of urothelium against freeze-damage by perfusion with warm saline prevented complications in adjacent

\section{Table 3. Relationship of tumour-free status attained after cryoablation to the number of cryoprobes and high and low Fuhrman grade mass lesions}

\begin{tabular}{lcc}
\hline & \multicolumn{2}{c}{ Fuhrman grade } \\
\hline No. cryoprobes & High* & Low* \\
\hline 1 & $4(3)$ & $1(1)$ \\
2 & $5(3)$ & $11(1)$ \\
3 & $10(3)$ & $16(0)$ \\
4 & $5(3)$ & $10(0)$ \\
5 & $4(2)$ & $2(0)$ \\
7 & $1(1)$ & $1(0)$ \\
Total no. & 29 & 41 \\
\hline
\end{tabular}

*(n) number of failed cryoablations. organs or urothelium injury in all but one of our patients. Based on our experience, percutaneous cryoablation is recommended as a minimally invasive nephron-sparing treatment for amenable lesions in older patients with medical comorbidities.

Competing interests: The authors declare no competing financial or personal interests.

This paper has been peer-reviewed.

\section{References}

1. Scolarius TA, Serrano MF, Grubb RL, et al. Effect of reclassification on the incidence of benign and malignant renal tumors. J Urol 2010;183:455-8. http://dx.doi.org/10.1016/i.juro.2009.10.045

2. Miller DC, Ruterbush J, Colts IS, et al. Contemporary clinical epidemiology of renal cell carcinoma: Insight from a population based case-control study. J Urol 2010;184:2254 -8. http://dx.doi.org/10.1016/i. juro.2010.08.018

3. Van Poppel H, Jonian S. Is surveillance an option for the treatment of small renal masses? Eur Urol 2007;52:1323-30. http://dx.doi.org/10.1016/i.eururo.2007.07.025

4. Rosales JC, Haramis $G$, Moreno J, et al. Active surveillance for renal cortical neoplasms. J Urol 2010;183:1698-702. http://dx.doi.org/10.1016/i.juro.2010.01.024

5. Allen $B C$, Remer $E$ M. Percutaneous cryoablation of renal tumors: Patient selection, technique and postprocedural imaging. Radiographics 2010;30:900 -7. http://dx.doi.org/10.1148/rg.304095134 


\section{Table 4. Relationship of tumour-free status attained after one cryoablation to cryoprobes deployed, size and location of} mass lesion

\begin{tabular}{|c|c|c|c|c|c|}
\hline \multirow[b]{2}{*}{ No. cryoprobes } & \multirow[b]{2}{*}{ Size mass } & \multicolumn{4}{|c|}{ Location } \\
\hline & & Posterior* & Postero-lateral* & Anterior* & Central and deep* \\
\hline 1 & $<2 \mathrm{~cm}$ & $4(1)$ & $2(1)$ & $1(1)$ & $5(1)$ \\
\hline 2 & $2-3 \mathrm{~cm}$ & $8(0)$ & $2(1)$ & 0 & $6(3)$ \\
\hline 3 & $2-3 \mathrm{~cm}$ & $7(0)$ & $2(1)$ & $2(1)$ & $8(2)$ \\
\hline 4 & $3-4 \mathrm{~cm}$ & $3(0)$ & 0 & $1(1)$ & $11(1)$ \\
\hline 5 & $3-4 \mathrm{~cm}$ & $4(0)$ & 0 & $1(1)$ & $1(1)$ \\
\hline 7 & $3-4 \mathrm{~cm}$ & $1(0)$ & 0 & 0 & $1(1)$ \\
\hline Total no. & & 27 & 6 & 5 & 32 \\
\hline
\end{tabular}

*(n) number of failed cryoablations.

6. Campbell SC, Novick A C, Belldegrun A, et al. Guidelines for management of clinical T1 renal mass. J Urol 2009;182:1271-9. http://dx.doi.org/10.1016/i.juro.2009.07.004

7. Schmit GD, Atwell TD, Callstrom MR, et al. Percutaneous cryoablation of renal masses of $>3 \mathrm{~cm}$ : Efficacy and safety in treatment of 108 patients. J Endourol 2010;24:1255-63. http://dx.doi.org/10.1089/ end.2009.0328

8. Rodriguez R, Cizman Z, Hong K, et al. Prospective analysis of the safety and efficacy of percutaneous cryoablation for TINxMx biopsy proven renal cell carcinoma. Cardiovasc Intervent Radiol 2011;34:573-8. htrp://dx.doi.org/10.1007/s00270-010-9934-7

9. Kunkle DA, Uzzo RG. Cryoablation or radiofrequency ablation of small renal mass: A metaanalysis. Cancer 2008;113:2671-80. http://dx.doi.org/10.1002/cncr.23896

10. Bandi G, Wen CC, Hedican SP, et al. Cryoablation of small renal masses: Assessment of outcome at one institution. BJU Int 2007;100:798-801. http://dx.doi.org/10.1111/i.1464-410X.2007.07158.x

11. Vricella GJ, Haaga JR, Adler AL, et al. Percutaneous cryoablation of renal masses: Impact of patient selection and treatment parameters on outcome. Urology 2011;77:649-54. http://dx.doi.org/10.1016/i. urology.2010.08.016

12. Zagoria RJ, Traver MA, Werle DM, et al. Oncologic efficacy of CT guided percutaneous radio-frequency ablation of small renal cell carcinoma. AJR Am J Roentgenol 2007;189:2129-34. http://dx.doi. org/10.2214/AJR.07.2258

13. Haber $G P$, Crouzet $S$, Remer EM, et al. Stereotactic percutaneous cryoablation for renal tumors: Initial clinical experience. J Urol 2010;183:884-8. http://dx.doi.org/10.1016/i.juro.2009.11.042

14. Breda A, Anterasian C, Bellegrun A, et al. Management and outcome of tumor recurrence after focal ablation renal therapy. J Endourol 2010;4:749-52. http://dx.doi.org/10.1089/end.2009.0658

15. Young JL, Kolla SB, Pick DL, et al. In vitro, ex vivo and in vivo isotherms for renal cryotherapy. I Urol 2010;183:752-8. http://dx.doi.org/10.1016/i.juro.2009.09.072

16. Long CJ, Kutikov A, Canter DJ, et al. Percuteneous versus surgical cryoablation of the small renal mass: Is efficacy compromised? BJU Int 2011;107:1376 -80. http://dx.doi.org/10.1111/j.1464410X.2010.09851.X

17. Strom KH, Derweesh I, Stroup SP, et al. Recurrence rates after percutaneous and laparoscopic renal cryoablation of small renal masses: Does the approach make a difference? J Endourol 2011;25:371-5. http://dx.doi.org/10.1089/end.2010.0239

18. Allaf ME, Lang EK. Bowel separation before percutaneous cryoablation. J Urol 2008;180:721-3. http:// dx.doi.org/10.1016/i.juro.2008.04.099

19. Bodily KD, Atwell TD, Mandrekar JN, et al. Hydrodisplacement in the percutaneous cryoablation of 50 renal tumors. AJR Am J Roentgenol 2009;194:779-83. http://dx.doi.org/10.2214/AJR.08.1570

20. Littrup PJ, Ahmed A, Aoun MD, et al. CT guided percutaneous cryotherapy, of renal masses. J Vasc Intervent Radiol 2007;18:383-92. http://dx.doi.org/10.1016/i.jvir.2006.12.007

21. Woolley ML, Schulsinger DA, Durand DB, et al. Effect of freezing parameters (freeze cycle and thaw process) on tissue destruction following renal cryoablation. J Endourol 2002;16:519-22. http://dx.doi. org/10.1089/089277902760367494

22. Porter CA IV, Woodrum DA, Callstrom MR, et al. MRI after technically successful cryoablation: Early contrast enhancement is a common finding. AJR Am J Roentgenol 2010;194:790-3. http://dx.doi. org/10.2214/AJR.09.2518
23. Stein AJ, Mayes JM, Mouraview V, et al. Persistent contrast enhancement several months after laparoscopic cryoablation of the small renal mass may not indicate recurrent tumor. J Endourol 2008;22:2433-9. http://dx.doi.org/10.1089/end.2008.0261

24. Squillaci E, Manenti G, Ciccio C, et al Perfusion CT monitoring of cryoablated renal cell tumors. J Exp Clin Cancer Res 2009;28:138-51. http://dx.doi.org/10.1186/1756-9966-28-138

25. Schmit GD, Atwell TD, Leibovich BC, et al. Percutaneous cryoablation of anterior renal masses: Technique, efficacy and safety. AJR Am J Roentgenol 2010;195:1418-22. http://dx.doi.org/10.2214/ AJR.09.3530

26. Rosenberg HD, Kim CY, Tsivian M, et al. Percutaneous cyroablation of renal lesions with radiographic ice ball involvement of the renal sinus: analysis of collecting system complications. AJR Am J Roentgenol 2011;196:935-9. http://dx.doi.org/10.2214/AJR.10.5182

27. Derweesh IH, Malcom JB, Diblasio CJ, et al. Single center comparison of laparoscopic cryoablation and CT guided percutaneous cryoablation for renal tumors. J Endourol 2008;22:2461-7. http://dx.doi. org/10.1089/end.2008.0196

28. Russo P. Should elective partial nephrectomy be performed for renal cell carcinoma $>4 \mathrm{~cm}$ in size? Nat Clin Pract Urol 2008;5:482-3. http://dx.doi.org/10.1038/ncpurol 177

29. Miller $\mathrm{DC}$, Hollingworth JM, Hafez $\mathrm{KJ}$, et al. Partial nephrectomy for small renal masses: An emerging quality of care concern? J Urol 2006;175:853-7. http://dx.doi.org/10.1016/S0022-5347(05)00422-2

30. Volpe A, Jewett MA. The natural history of small renal masses. Nat Clin Pract Urol 2005;2:384-90. http://dx.doi.org/10.1038/ncpuro0254

31. Kramer BA, Whelan CM, Vestal IC, et al. RF. Increasing the number of biopsy cores before renal cryoablation increases the diagnostic yield. J Endourol 2009;21:283-6. http://dx.doi.org/10.1089/end.2008.0347

32. Park SH, Kang SH, Ko YH, et al. Cryoablation for endophytic renal cell carcinoma: Intermediateterm oncologic efficacy and safety. Korean J Urol 2010;51:518-24. http://dx.doi.org/10.4111/ kju.2010.51.8.518

33. Link RE, Bhayani SR, Allaf ME, et al. Exploring the learning curve, pathological outcomes and perioperative morbidity of laparoscopic partial nephrectomy performed for renal mass. J Urol 2005; 173:1890-4. http:// dx.doi.org/10.1097/01.ju.0000154777.24753.1b

34. Atwell TD, Callstrom MR, Farrell MA, et al. Percutaneous renal cryoablation: Local control at mean 26 months followup. J Urol 2010;184:1291-5. http://dx.doi.org/10.1016/i.juro.2010.06.003

35. Tsivian $M$, Chen V, Kim CY, et al. Complications of laparoscopic and percutaneous renal cryoablation in a single tertiary referral center. Eur Urol 2010;58:142-7. hittp://dx.doi.org/10.1016/i.eururo.2010.03.035

36. Sidana A, Aggarawal P, Feng Z, et al. Complications of renal cryoablation: A single center experience. J Urol 2010;184:42-7. http://dx.doi.org/10.1016/i.juro.2010.03.013

Correspondence: Dr. Kan Karl Zhang, Duke University Medical Center, Room 1570, White Zone, 200 Trent Drive, Durham, NC 27710; karczar@gmail.com 